\title{
Environmental Impacts of COVID-19: A Study of Ghana
}

\author{
Richard Agyemang $^{1 *} \quad$ Osei Boateng Prince ${ }^{2} \quad$ Stephen Agyeman-Yeboah ${ }^{3}$ \\ 1.Kwame Nkrumah University of Science and Technology, PMB, KNUST, Kumasi \\ 2. University of Ulsan, Department of Architecture and Urban Planning, South Korea \\ 3. Kwame Nkrumah University of Science and Technology
}

\begin{abstract}
Aim of this study is gathering secondary data and portrays a picture of the environment of Ghana under pandemic effects. Global spread of COVID-19 for quite a short time brought a considerable reduction in industrial activities, road traffic and tourism. Restricted human interaction with nature during this crisis time has appeared as a blessing for nature and environment. Reports from all over the world are indicating that after the outbreak of COVID-19, environmental conditions including air quality and water quality in rivers are improving and wildlife is blooming. Ghana has always been a hub of pollution with huge population, heavy traffics and polluting industries leading to high air pollution in the capital of Ghana-Accra. After the implementation of lockdown by the government of Ghana due to COVID-19, air quality improved and other environmental indicators such as water quality in rivers gave a positive sign towards restoring. The lockdown also had its negative effects on the environment. This study provides evidence-based insight into improvement of air quality, noise pollution during pre and post lockdown of this pandemic. Air quality indicators $\mathrm{PM}_{2.5}, \mathrm{PM}_{10}$ and $\mathrm{NO}_{2}$ concentrations were factored in the analysis of the study. The study also observed no significant improvement in land littering before and after the lockdown period as face masks, coverings and plastic hand sanitizers added to the existing volume of waste in the environment.
\end{abstract}

Keywords: Air quality, land littering, noise pollution, carbon emission, ozone layer.

DOI: $10.7176 / \mathrm{JEES} / 11-12-03$

Publication date: December $31^{\text {st }} 2021$

\section{Introduction}

The world faced number of pandemic diseases from man history resulting in millions of people dying from every pandemic disease. History of pandemic diseases started from that time when peoples have no industrial revolution like current developed world. Every pandemic that the world faced from history does not only affects the lives of people but also leads to economic crises, poverty and other health problem. In the past, world face pandemic diseases, Antonin Plague in 165 AD, 5 million people died and it was very huge number according to that era, from Plague of Justinian, 25 million people died during the period of 541 to 542, from The Black Death during 1346 to 1353 in Asia, Europe, and Africa ,75 to 200 million people died, from Flu in 1918 to 1920, 50 million people died, from Asian Flu, 2 million people died in 1956 to 1958, HIV/AIDS reached at peak from 2005 to 2012 and 36 million people died (Hays 2005, Ligon 2005, Barry 2010).

The current pandemic that has now become a challenge Worldwide is COVID-19 also known as Coronavirus disease caused by severe acute respiratory syndrome Coronavirus 2 (SARS-CoV-2). With regards to the issue of Coronavirus (2019), the first case was reported to World Health Organization (WHO) country office in Wuhan, China on $31^{\text {st }}$ December, 2019 with symptoms of unexplained low respiratory infections. This was categorized as "pneumonia of unknown etiology" as the cause of infection was not known. WHO found that Coronavirus was the cause of this infection on $12^{\text {th }}$ January, 2020 and on the $11^{\text {th }}$ of February, the General-Director of WHO declared this novel CoV as 'COVID-19' which is an acronym of 'Corona virus disease 2019(Cascella et al.,2020). Covid19 contain a single-stranded RNA as nuclei material and are $65 \mathrm{~nm}-125 \mathrm{~nm}$ in diameter (shereen et al.,2020). Coronavirus was considered to be a pandemic limited to China and according to Wu and Mcgoogan,2020, the World Health Organization (WHO) declared the outbreak a public Health Emergency of International Concern on $30^{\text {th }}$ January. USA, Spain, Italy, France, Germany, Iran, Turkey, China and UK are most affected countries from this pandemic. In USA alone, more than one million cases were reported (Barrios and Hochberg 2020, Sohrabi, Alsafi et al. 2020). As of $3^{\text {rd }}$ August, 2020, more than 18 million cases have been reported in more than 188 countries and territories, resulting in more than 689,000 death; more than 10.6 million people have recovered (WHO, 2020).

Ghana's COVID-19 case was reported on $12^{\text {th }}$ March, 2020 by the Minister of Health, Kwaku Agyemang Manu at an emergency press briefing of Ghana's first two cases in Accra. The two cases were people who returned to the country from Norway and Turkey which made them the first actual cases of COVID-19 in Ghana. These two cases began the first contact tracing process in Ghana. Of the first two cases reported in Ghana, one case was a senior officer at the Norwegian Embassy in Ghana who had returned from Norway, while the other was a staff member at the United Nations (UN) offices in Ghana who had returned from Turkey (Duncan, Jude 2020 and Anyorigya, Daniel 2020). Since then, the virus has spread to other part of the country. The current confirmed cases in Ghana is 37,014 and out of this, 33,655 have recovered with 182 deaths. In response to this pandemic, Ghana's 
president Nana Akufo- Addo began delivering a series of state of the nation addresses concerning COVID-19 in March by announcing that the cedi equivalent of 100 Million US dollars (Ministry of Health,2020) would be made available to enhance Ghana's preparedness and response plan. Initially the Government of Ghana banned all public gatherings including conferences, workshops, funerals, festivals, political rallies, church activities and other related events to reduce the spread of the virus. Beaches were also closed. Basic schools, senior high schools and universities, both public and private, were also closed. Only BECE and WASCE candidates were permitted to remain in school under social distancing protocols Nyabor, Jonas 2020). Traveling to Ghana from countries which had recorded over 200 positive COVID-19 cases was strongly discouraged with non-admittance of such traveler's; this restriction did not however apply to Ghanaian citizens and people with resident permits (Duncan, Jude 2020). All of the country's borders were later closed for two weeks from midnight of Sunday $22^{\text {nd }}$ March, 2020 and Passport services were also suspended (Graphic Online). On 30 March, the partial lock down of Accra and Kumasi took effect( Acheampong, Kwame,2020) Members of the Executive, Legislature and the Judiciary; and some services such as those that were involved in the production, distribution and marketing of food, beverages, pharmaceuticals, medicine, paper and plastic packages, media and telecommunications were exempted from the restrictions. The border closure was extended by the president, for another two-weeks effective midnight of Sunday 5 April 2020 and mandatory use of masks was to be enforced by businesses and organizations.

The world disruption caused by COVID-19 pandemic has resulted in numerous impacts on the environment and climate. The considerable decline in planned travel has caused many regions to experience a large drop in air pollution (Team, the Visual and Data Journalism, 2020). In China, lockdowns and other measures resulted in 25 percent reduction in carbon emissions (Myllyvirta,Lauri,2020) and 50 percent reduction in Nitrogen oxide emissions Zhang, Ruixiong; Zhang, Yuzhong; Lin, Haipeng; Feng, Xu; Fu, Tzung-May; Wang, Yuhang (April 2020) which one Earth Systems Scientist estimated may have saved at least 77,000 lives over two months(Burke, Marshall, 2020 and McMahon, Jeff, 2020). Other positive impacts on the environment include governance system-controlled investments towards a sustainable energy transition and other goals related to environmental protection such as the European Union's seven -year $€ 1$ trillion budget proposal and $€ 750$ billion recovery plan "Next Generation EU" which seeks to reserve 25\% of EU spending for climate-friendly expenditure (Simon, Frédéric 2020 and Carpenter, Scott 2020).The main objective of the study is to investigate the environmental impacts of COVID-19 in Ghana specifically;(I) examining the impacts on air quality; (ii) the impact on land ;(iii) Ozone layer and;(iv) impact on noise pollution. This can assist policy makers in Africa to plan adequately in the management of COVID-19 to reduce the impacts on the populace.

\section{Description of Method}

Secondary information was generated from research papers, scholarly articles, technical reports, and policy documents in order to situate the research within the context of the wider body of knowledge and literature. Information on the total number of cases on number of confirmed cases and death cases, air quality values guidelines was gathered from the World Health Organization (WHO) online database. Records available with Ghana Health Service on COVID-19 were also employed for this study. Data on permissible ambient noise in Ghana was obtained from the Environmental Protection Agency (EPA), Ghana.

\section{Description of the Study Area}

Accra, the capital and the largest city of Ghana, on the Gulf of Guinea (An arm of the Atlantic Ocean). Accra's 2020 population is now estimated at 2,514,005. Accra has grown by 224,444 since 2015, which represents a $1.89 \%$ annual change. These population estimates and projections come from the latest revision of the UN World Urbanization Project. These estimates represent the Urban agglomeration of Accra, which typically includes Accra's population in addition to adjacent suburban areas. Accra's urban area covers 225.67 square kilometers of land while the entire metropolis has grown to nearly 900 square kilometers. In the metro area, the population density is approximately 1,300 people per square kilometer. The city has adverse pollution problems mainly due to traffic congestion and dust. Air pollutants such asPM $\mathrm{PM}_{2.5}, \mathrm{PM}_{10)}$ and $\mathrm{NO}_{2}$ concentration in the atmosphere was at a very high degree which could not be controlled by the government through several efforts and preventive measures. Therefore, Accra was selected as the study area and the things changed there in early 2020 when Government of Ghana (GOG) declared a complete lockdown in the country in order to prevent community transmission of corona virus. Similar steps were also taken in various part of world which negatively influenced the economy of those countries but had a positive impact on overall air quality (World Economic Forum,2020).

\section{Results and Discussion}

4.1 Study of air quality through pollutants concentration $\left(P M_{2.5}, P M_{10}\right)$ and $\left.\mathrm{NO}_{2}\right)$

Air emissions have natural or anthropogenic origins with the latter focuses on industrial activities and burning of fossil fuels. Outdoor air pollution is a major environmental health problem affecting everyone in low-, middle-, 
and high-income countries. Ambient (outdoor) air pollution in both cities and rural areas was estimated to cause 4.2 million premature deaths worldwide per year in 2016; this mortality is due to exposure to small particulate matter of 2.5 microns or less in diameter $\left(\mathrm{PM}_{2.5}\right)$, which cause cardiovascular and respiratory disease, and cancers According to WHO (2016), air pollution kills an estimated seven million people worldwide every year. WHO (2018) data shows that 9 out of 10 people breath air containing high level of pollutants. Air pollution is of two types namely indoor and outdoor pollution. Indoor air pollution refers to the chemical, biological and physical contamination of indoor air. It may result in adverse health effects. In developing countries like Ghana, the main cause of indoor pollution is cooking, smoking, heating appliances and to name a few which contains suspended particulate matter (5PM), nitrogen dioxide (NO2), sulfur dioxide (SO2), carbon monoxide (Ca), formaldehyde and polycyclic aromatic hydrocarbons (PAHs). Millions of people around the world prepare their meals using traditional methods (i.e., wood, charcoal, coal, dung, crop waste) on open fire. Such inefficient practices can increase the amount of air pollutant in our homes and cause serious health problems.

According to WHO,2016, 4.3 million people die a year on exposure to household air pollution. Since March,2020, indoor activities are not affected by the Coronavirus pandemic but rather outdoor activities. Outdoor pollution arises from anthropogenic activities. Anthropogenic sources are related to the production and combustion of different fuels. Human activities are responsible for the increases in ground-level O3 and GHGs in recent years. About $95 \%$ of NOx (nitric oxides) from human activity come from the burning of fossil fuels in power plants, engines, homes, and industries. Air emissions are the byproducts of energy production and consumption. Major form of outdoor air pollution includes NOx, Cox, Particular matter (PM2.5 and PM10), Ozone (O3), Volatile organic compounds (VOCs) and Sulfur dioxide (SO2). Main sources of these pollutants are industrial emission and automobile exhaust (Kumar, Nagar et al. 2007, Chen, Brager et al. 2019). The above pollutant contributes significantly to air pollution which has negative impacts on the environment and also causes serious health problems.

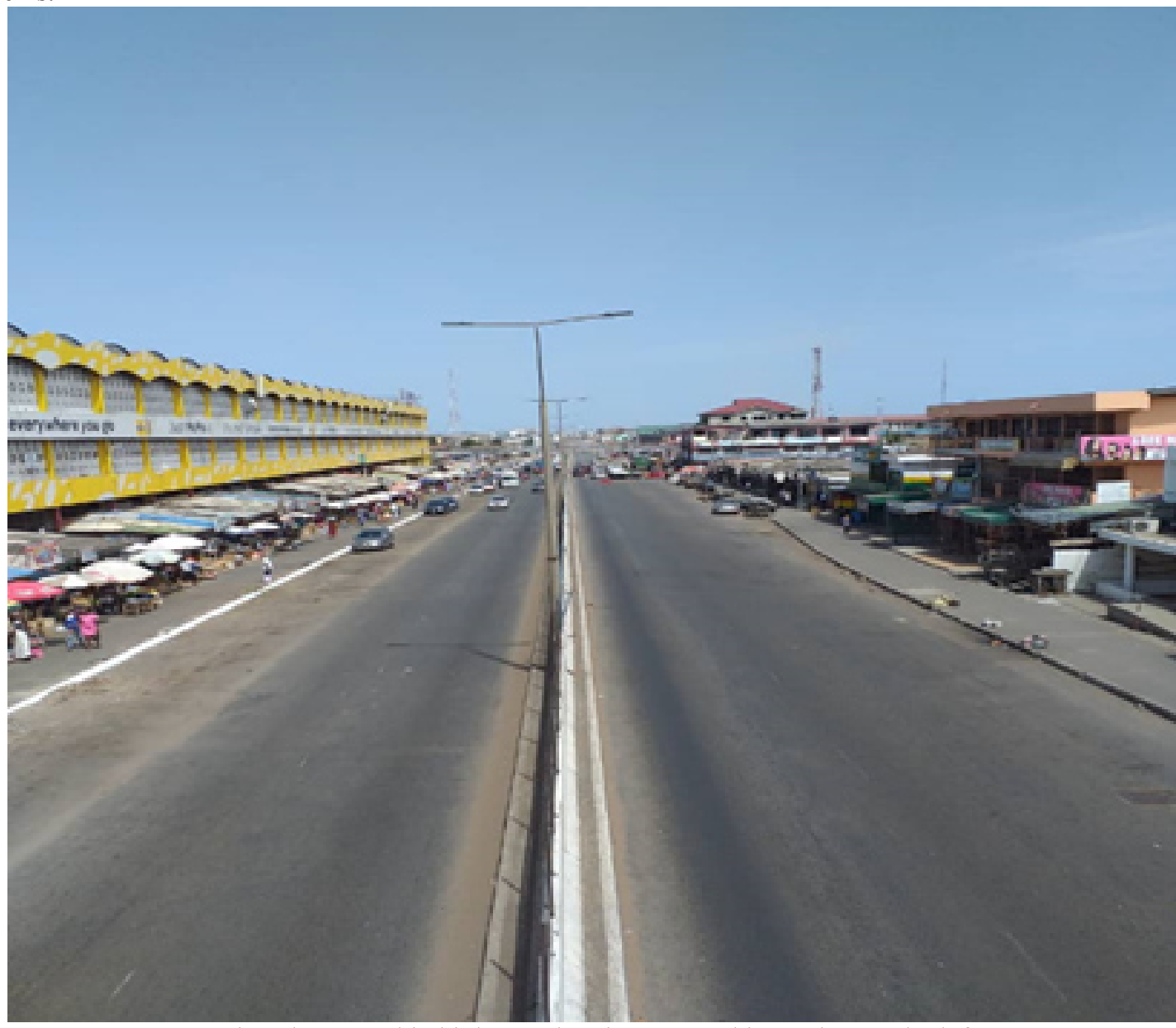

Fig1The Kaneshie highway showing Kanseshie market on the left

Source: Environmental Protection Agency (EPA).

Fig 1 shows the street of Kaneshie during the lockdown restrictions being implemented by the president of Ghana, Nana Akufo-Addo. After a few weeks of lockdown measures, restricting people and vehicular movement, there have been an observable and drastic in traffic and air pollution in the capital of Ghana- Accra, (Kaneshie). 
In order to study the environmental impact of lockdown on air quality in Accra, average daily readings concentrations of three major pollutants of specific dates were compared to the concentration data of pre and post COVID-19 period. The three major pollutants include Nitrogen Oxide (NO2), $\mathrm{PM}_{2.5}$ and $\mathrm{PM}_{10}$. During the lockdown human activities including transportation and industries in Accra, the pollutant levels dropped down significantly. Due to the Coronavirus impact on travel and industry, many regions and the planet as a whole experienced a drop in air pollution. Reducing air pollution can reduce both climate change and COVID-19 risk (editor, Damian Carrington Environment, 2020). Quarantining and lockdowns have forced manufacturing industries in Ghana to shut down. The Government of Ghana banned all public gatherings including conferences, workshops, funerals, festivals, political rallies, church activities and other related events to reduce the spread of the virus. These restrictions undertaken by the government of Ghana to curb the pandemic reduces the emission of nitrogen dioxide $\left(\mathrm{NO}_{2}\right), \mathrm{PM}_{2.5}$ and $\mathrm{PM}_{10}$ which are major pollutants, which are in turn indicative of economic activities and are closely linked to factory output and vehicles on the roads.

Table 1.1 WHO Air quality values guidelines

\begin{tabular}{|l|l|l|}
\hline Air quality indicator & Annual mean & 24-hour mean \\
\hline Fine particulate matter $\left(\mathrm{PM}_{2.5}\right)$ & $10 \mu \mathrm{g} / \mathrm{m}^{3}$ & $25 \mu \mathrm{g} / \mathrm{m}^{3}$ \\
\hline Coarse particulate matter (PM10) & $20 \mu \mathrm{g} / \mathrm{m}^{3}$ & $50 \mu \mathrm{g} / \mathrm{m}^{3}$ \\
\hline
\end{tabular}

Source: World Health Organization (2016)

Table 1.1 above shows the guideline values of quality air indicator by WHO. In addition to the guideline values, the WHO air quality guidelines provide interim targets for concentrations of $\mathrm{PM}_{10}$ and $\mathrm{PM}_{2.5}$ aimed at promoting a gradual shift from high to lower concentrations. Accra, Ghana's capital city, has the worst air pollution in Ghana, according to all publicly available data (Ghana Environmental Protection Agency,2016). Before the lockdown, the $\mathrm{PM}_{2.5}$ annual mean concentrations in Accra was more than 5 times above the safe limits set by the WHO - 55 $\mathbf{\mu g} / \mathbf{m 3}$. The $\mathrm{PM}_{10}$ annual mean concentrations in Accra in 2015 was one of the worst in the world (172 $\boldsymbol{\mu g} / \mathbf{m} 3$ compared with the WHO annual guideline of $20 \mu \mathrm{g} / \mathrm{m} 3)$. Particulate matter $\left(\mathrm{PM}_{2.5}\right.$ and $\left.\mathrm{PM}_{10}\right)$ an indicator of air quality originates from various emission sources like industries, power plants, refuse burning and road dust re-suspension etc. As lockdown restricted all these activities in entire country, its direct impact on PM concentration is inevitable. During the lockdown as a preventive measure to avoid the spread of the virus, $\mathrm{PM}_{10}$ and $\mathrm{PM}_{2.5}$ concentration reduced thus improving the air quality.

There was also a significant reduction in Nitrogen dioxide $\left(\mathrm{NO}_{2}\right)$ levels (generally emitted in the atmosphere through vehicular exhausts, power plants and industries) due to movement restrictions. There is a strong correlation between the lockdown and concentration of pollutants in the atmosphere. This imply that control of local transportation and limited industrial activities has decreased the overall pollution load on air.

\subsection{Impact on the ozone layer}

The ozone layer or ozone shield is a region of Earth's stratosphere that absorbs most of the sun's ultraviolet radiation. It contains a high concentration of ozone in relation to other parts of the atmosphere. Ozone depletion, gradual thinning of the Earth's Ozone layer in the upper atmosphere caused by the release of chemical compounds containing gaseous chlorine or bromine from industries and other human activities. Depletion of ozone layer allow harmful UV light pass through them that cause skin cancer, eye effect, and human immunity system effect (Solomon, Ivy et al. 2016, Chipperfield, Bekki et al. 2017). A study published in May 2020 found that the daily global carbon emissions during the lockdown measures in early April fell by $17 \%$ and could lead to an annual emission decline of up to $7 \%$, which would be the biggest drop since World II according to research. They ascribe these decreases mainly to the reduction of transportation usage and industrial activities (NBC News,2020). The world's demand for fossil fuels has decreased by almost $10 \%$ amid coronavirus measures and reportedly many energy economists believe it may not recover from the crisis (Ambrose, Jillian 2020). During the lockdowns measures in Ghana, industries were shut down, movement were restricted. Human activities such as burning of fossil fuels, deforestation and farming activities reduced. These activities are major contributor to global warming, the increase in temperature of the atmosphere caused by concentration of greenhouse gases in the atmosphere which indirectly helpful for the ozone layer.

\subsection{Impact on land}

In accordance with the government measures to combat Coronavirus pandemic, millions of people globally have started to wear face masks and facing coverings and also the use of hand sanitizers to disinfect the hands. The government of Ghana undertook these measures as a preventive mechanism to the virus making it mandatory for everyone to wear face masks with serious fines imposed to those who goes contrary to the measures being put in place. Although this does contribute to slowing down the spread of the virus, the exponential use of disposable face masks is having a profound effect on the environment that seems to be overlooked. Some of these face masks and coverings are made of plastics. Plastic pollution is the accumulation of plastic objects and particles (e.g., plastic bottle bags, plastic hand sanitizers, and microbeads) in the Earth's Environment adversely affects wildlife, 
wild life habitats and humans (Laura Parker, 2018). However, the chemical structure of most plastics renders them resistant to many natural processes of degradation and as a result they are slow to degrade (Le Guern, Claire, 2018). Plastic pollution on land poses a threat to the plants and animals - including humans who are based on the land. estimates of the amount of plastic concentration on land are between four and twenty-three times that of the ocean. The amount of plastic poised on the land is greater and more concentrated than that in the water (unenvironment.org,2018).

\subsection{Impact on noise}

In Ghana, permissible ambient noise as set by the environmental protection agency(EPA) requires that during the day, noise levels should not be above 55 decibels during the day and 48 at night (EPA,2008). There is no doubt that the level of noise pollution in Accra is above the ambient level 55 decibels.. It has become a cancer that many inhabitants of the city have become adapted to live with. This is due to the fact that, many believe that there is nothing anyone can do to stop the nuisance of noise making and its associated discomfort. Many inhabitants are unaware of the effect of excessive noise. Some even think it is a natural phenomenon that no one should even worry about.

Noise can be defined as any complex sound waves that are a periodic, in other words, sound waves with irregular vibration and no definite pitch. One may ask, why should we be perturbed about excessive noise? Noise levels are measured in decibels $(\mathrm{dB})$. The higher the decibel level, the louder the noise. Experts say, sounds louder than 80 decibels are considered potentially hazardous. This is not a welcoming fact to many of us especially when Accra has become the noise hub of the country. Many manufacturing companies whose activities are routinely associated with loud noise are illegally situated right in the midst of residence areas. People who live in these locations are constantly exposed to continuous loud and excessive noise. One cannot complain much about the excessive noise level at market centers. In this part of the world, shouting is the traditional and an acceptable way seller at market centers draw attention of customers to their goods unlike other countries, where the power of the internet and other modern technologies are harnessed to serve the same purpose.

Another disturbing illegal practice that is gradually becoming a norm in the city is the sales of music CDs and cassettes on mobile tracks. These mobile music hawkers open their sound systems so loud that one can hardly bear the noise that emanates from them. All in the name of marketing their products, they care or know less about the harm they are causing themselves and others. The stationary music sellers are equally guilty of this illegality. Because the city authorities are doing very little to curb this new illegal practice many more people are joining the trade day in and out. As a means of attracting customers, drinking bars open their sound system so loud that one can hear their music as far as $300 \mathrm{~m}$ away. Those who patronage these drinking bars call this noise enjoyment or fun. Neighbors complain but their complaint has no remedy because many of these drinking bar operators have permits and the law concerning excessive noise is hardly enforced. Some churches are equally guilty of noise pollution in the city. Many churches sing loudly and beat drums from Monday to Sunday. It is good to serve God as Christians but opening sound instrument to a point that may cause harm to others and ourselves becomes even a 'sin'.

Nowadays nightclubs are everywhere, and most of them are built with no noise restraining gadgets to impede the sound from causing nuisance to people who live around. On occasions such as traditional funerals and marriage engagements people are exposed to excessive and dangerous noise. Overwhelmed with joy, the music is made so loud to a point that is harmful to human health; they hardly consider the possible effect loud noise can have on them and other who are not in the happy mood with them. Sadly, this and many other similar activities have become part of us because no one seems to care or know about the dangers associated with noise pollution

During the lockdown measure as a preventive action taken to address the spread of corona virus in the country, manufacturing industries were shutdown, restrictions on travelers, reduction in traffic linked to road, the closing down of churches and social gathering reduce the noise pollution during that period. 


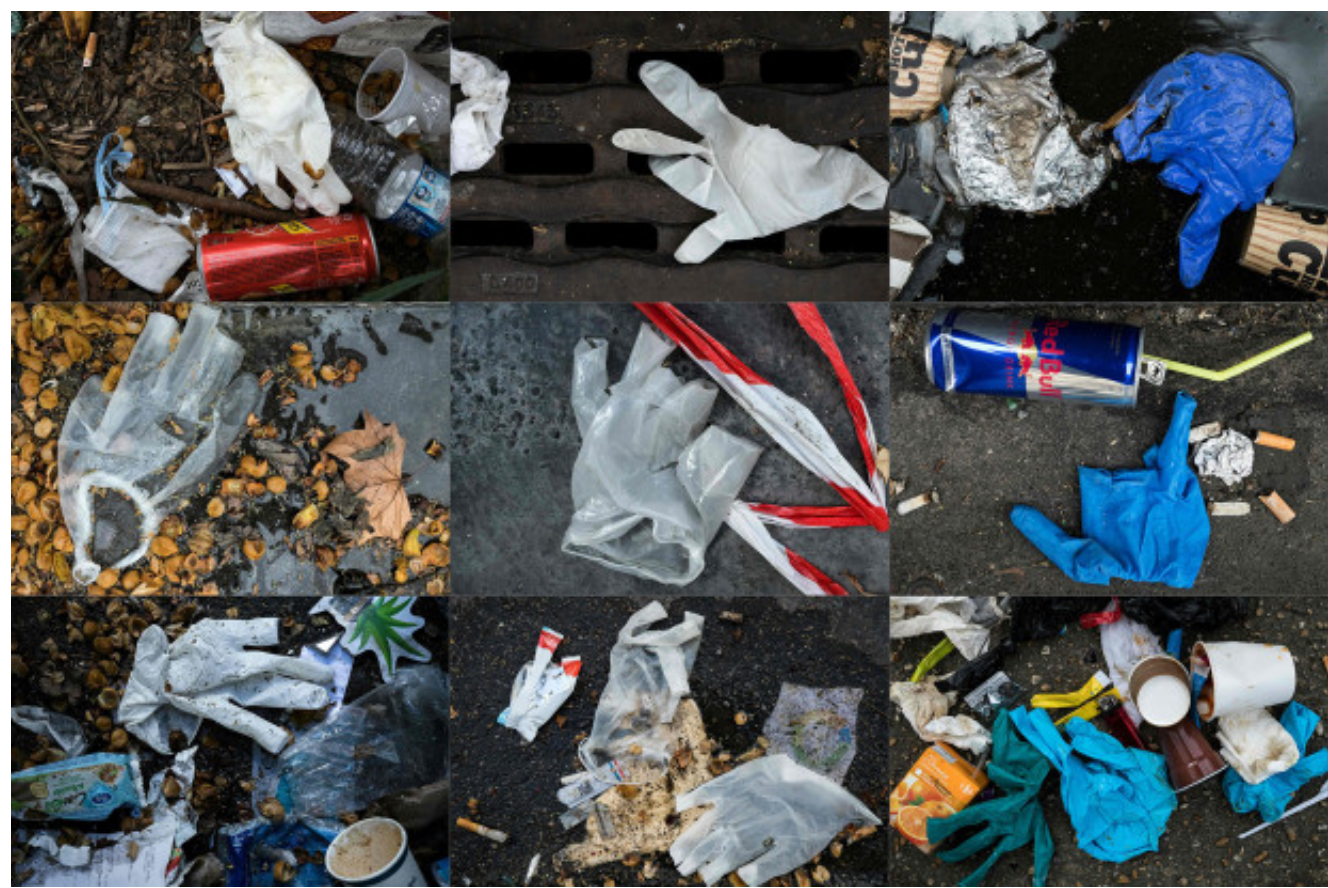

Fig 2 shows part of Kumasi-Adum being littered by hand gloves, face marks due the virus.

Source: Environmental Protection Agency (EPA)

As a consequence of the unprecedented use of disposable face masks, a significant number of masks were discarded in the natural environment, adding to the burden of plastic waste in municipal areas of the country. During COVID-19 pandemic, plastics demand for medical usage has increased considerably in all the regions in Ghana. Besides personal protective equipment (PPE) such as masks and gloves, a considerable increase in plastic usage has been related to requirements packaging, and single-use items. Collectively, these shifts in hospitals and regular life may exacerbate environmental issues with plastics, which already existed even before the pandemic occurred. Also tissues and other materials used for sneezing or coughing are thrown haphazardly in to the environment making it unfriendly.

\section{TOTAL CASES}

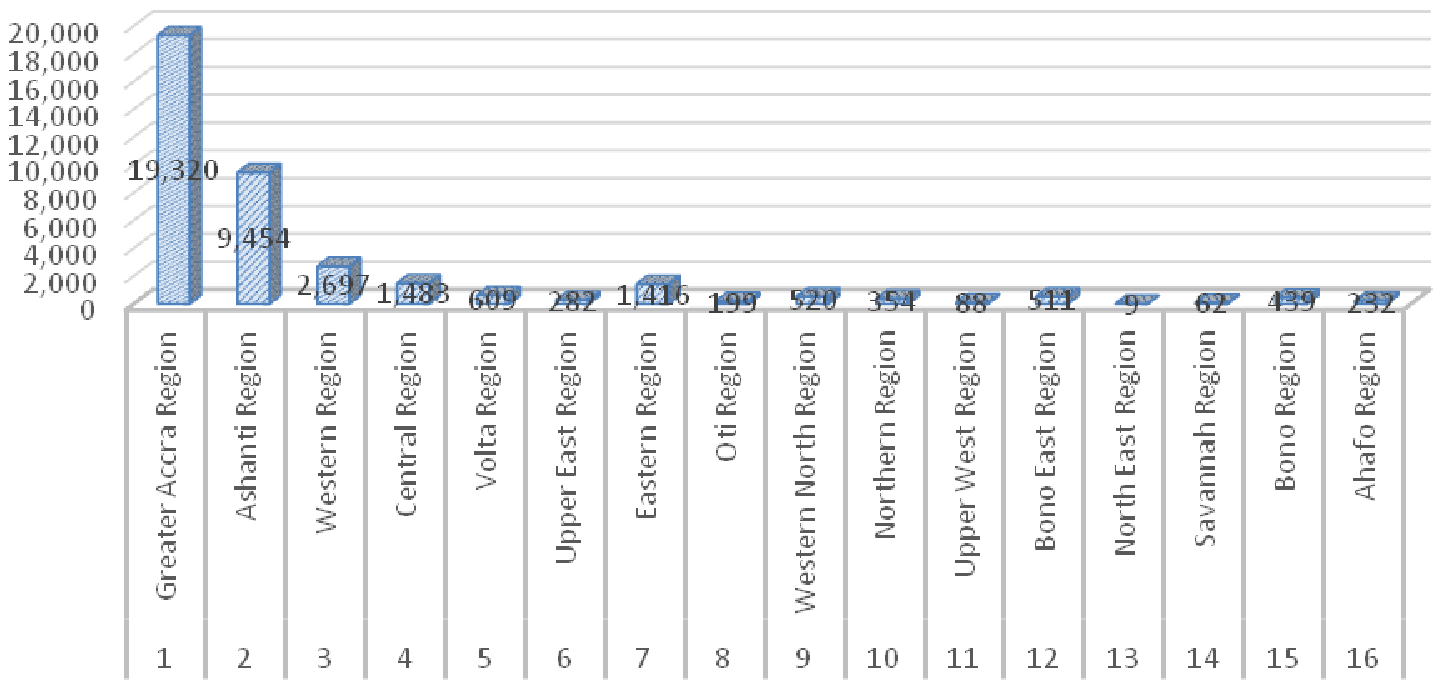

Source: Ghana Health Service, 2020.

Fig 3 shows total number of confirmed cases in all the regions in Ghana.

From Fig 3 Greater Accra recorded the highest number of confirmed cases in the country.

This shows the increased in demand for face masks, coverings and plastic hand sanitizers. Improper disposal of the used face masks, coverings and plastic hand sanitizers degrades the land. Ashanti Region recorded the second highest confirmed cases in all the 16 regions. Northern East Region recoded the least number of confirmed 
cases in all the regions. This means that, there is less demand of face masks and covering in this region. It could be concluded that, there is less littering on land in the Northern East Region.

\section{Conclusion and future directions}

COVID-19 which started in Wuhan in December 2019, has now affected 215 countries across the globe with $18,732,987$ confirmed cases with 705,042 death cases as on $5^{\text {th }}$ August 2020. On the same day Ghana has reported to have 37,812 confirmed cases with 191 deaths (worldometer's covid-data,2020) The condition is still uncontrolled and with no proven cure for the virus. Oxford Vaccine Group and the Jenner Institute, who are veterans when it comes to combating epidemics are about to start trials in healthy young volunteers in the Thames Valley region, to test the new $\mathrm{ChAdOx} 1 \mathrm{nCoV}-19$ vaccine .Locking down in homes and social distancing is the only preventive step that the entire country is following. But as the human activities are restricted in most of the areas, the natural environment of country has started healing itself. Factories, transport, vehicles and aviation have all ground to a halt. Carbon emissions have decreased and the quality of air has seen an unprecedented improvement. It is remarkable that $\mathrm{PM}_{2.5}, \mathrm{PM}_{10}$ and $\mathrm{NO}_{2}$ in one of the most populated city of Ghana (Accra) decreased after the lockdown period to curb the coronavirus. After reviewing various reports as cited earlier, it can be summarized that undoubtedly COVID-19 has brought a fearful devastating scourge for human being but it has emerged as a blessing for natural environment providing it a "recovery time". We have also learnt that the environmental degradation caused by humans is not totally irreversible. In a period of just 1-2 months, "recovery of nature" is being witnessed by everyone. This is a signal for us to understand and react. Government and Policy makers should take necessary steps so that this healing process does not become a temporary thing. The research focusses on the changes in air quality, land littering and noise pollution during the lockdown period. There is a need for rigorous study on the effect of implementation of such short-term lockdown as an alternative measure for pollution reduction and its effect on economy. This study may also be used as a reference document to analyze post COVID-19 condition as well to analyze effect of reduced pollution on health data of sensitive receptors. At present, when the entire globe is struggling to frame proper strategies to combat COVID-19, the early lockdown implemented has shown an absolute way towards restoring ecosystem and environment. This study is sort of invitation for the future researchers to work on this topic in more scientific way to understand this phenomenon in holistic way. This study is conducted in Ghana and this same can be carried on other geographical locations.

\section{Reference}

[1] Acheampong, Kwame, (2020). "Covid-19: Accra, Kumasi empty as lockdown takes effect | Starr Fm"

[2] Ambrose, Jillian, (2020). "Coronavirus crisis could cause \$25tn fossil fuel industry collapse". The Guardian.

[3] Anyorigya, Daniel, (2020). "Coronavirus: Norwegian Embassy in Ghana shuts down after staff member tested positive". Citi Newsroom

[4] Barrios, J. M. and Y. V. Hochberg (2020). "Risk perception through the lens of politics in the time of the COVID-19 pandemic." University of Chicago, Becker Friedman Institute for Economics Working Paper (2020-32).

[5] Barry, J. M. (2010). "The next pandemic." World policy journal 27(2): 10-12.

[6] Burke, Marshall, (2020). "COVID-19 reduces economic activity, which reduces pollution, which saves lives". Global Food, Environment and Economic Dynamics.

[7] Carpenter, Scott, (2020. "As Europe Unveils 'Green' Recovery Package, Trans-Atlantic Rift on Climate Policy Widens". Forbes.

[8] Chen, J., et al. (2019). "Impact of outdoor air quality on the natural ventilation usage of commercial buildings in the US." Applied Energy 235: 673-684.

[9] Chipperfield, M. P., et al. (2017). "Detecting recovery of the stratospheric ozone layer." Nature 549(7671): 211-218.

[10] Duncan, Jude (2020). "Two cases of coronavirus confirmed in Ghana". Citi Newsroom.

[11] Editor, Damian Carrington Environment (2020). "Air pollution linked to far higher Covid-19 death rates; study finds". The Guardian. ISSN 0261-3077

[12] Environmental Protection Agency, (2008)." Ghana required ambient on sound" retrieved fromttps://www.google.com/search?q=ghana+ambient+required+sound\&oq=ghana+ambient+required + sou nd\&aqs $=$ chrome.69i57j33.45080j0j7\&sourceid $=$ chrome\&ie $=U T F-8$

[13] "Global carbon emissions dropped 17 percent during coronavirus lockdowns, scientists say". NBC News, (2020)

[14] Graphic Online,(2020)."Ghana closes its borders for 2 weeks to fight Coronavirus".

[15] Graphic online,(2020)."All beaches in Ghana closed to fight Coronavirus".

[16] Hays, J. N. (2005). Epidemics and pandemics: their impacts on human history.

[17] Kumar, R., et al. (2007). "Association of indoor and outdoor air pollutant level with respiratory problems among children in an industrial area of Delhi, India." Archives of environmental \&occupational health 62(2): 
$75-80$.

[18] Laura Parker (June 2018). "We Depend on Plastic. Now We're Drowning in It". NationalGeographic.com.

[19] Le Guern, Claire (2018). "When the Mermaids Cry: The Great Plastic Tide". Coastal Care. Archived from the original on 5 April 2018.

[21] M.A. Shereen, S. Khan, A. Kazmi, N. Bashir, R. SiddiqueCOVID-19 infection: origin, transmission, and characteristics of human coronaviruses

[21] McMahon, Jeff (16 March 2020). "Study: Coronavirus Lockdown Likely Saved 77,000 Lives in China Just by Reducing Pollution". Forbes.

[22 M. Cascella, M. Rajnik, A. Cuomo, S.C. Dulebohn, R.D. Napoli Features, (2020) "Evaluation and Treatment Corona Virus (COVID-19)", NCBI Bookshelf

[23] Ministry of Health,(2020) ""\$100 Million Provided To Enhance Coronavirus Preparedness And Response Plan" - President Akufo-Addo". Ministry of Health.

[24] Nyabor, Jonas (2020). "Coronavirus: Government bans religious activities, funerals, all other public gatherings". Citi Newsroom.

[24] Simon, Frédéric (2020). "'Do no harm': EU recovery fund has green strings attached". www.euractiv.com

[25] Sohrabi, C., et al. (2020). "World Health Organization declares global emergency: A review of the 2019 novel coronavirus (COVID-19)." International Journal of Surgery.

[26] Team, The Visual and Data Journalism (28 March 2020). "Coronavirus: A visual guide to the pandemic". $B B C$ News

[26] World Economic Forum, (2020). The Deadly Link between COVID-19 and Air Pollution.https://www.weforum.org/agenda/2020/04/the-deadly-link-between-covid-19-and-air-pollution

[27] Wu, Z. and J. M. McGoogan (2020). "Characteristics of and important lessons from the coronavirus disease 2019 (COVID-19) outbreak in China: summary of a report of 72314 cases from the Chinese Center for Disease Control and Prevention." Jama.

[28] Zhang, Ruixiong; Zhang, Yuzhong; Lin, Haipeng; Feng, Xu; Fu, Tzung-May; Wang, Yuhang (2020). "NOx Emission Reduction and Recovery during COVID-19 in East China". Atmosphere 